\title{
Prinsip Public Relations dalam Ajaran Islam Menurut Persepsi Anggota Perhumas Jawa Tengah
}

\author{
${ }^{1}$ Trimanah, ${ }^{2}$ Diah Wulandari \\ Prodi Ilmu Komunikasi Universitas Islam Sultan Agung, Jln. Raya Kaligawe KM. 4 Semarang. \\ Email: ${ }^{1}$ trimanah@unissula.ac.id, ${ }^{2}$ diahwulandari@unissula.ac.id
}

\begin{abstract}
Abstrak. Public Relations merupakan satu keilmuan dan juga profesi yang berkaitan dengan upaya membangun hubungan baik dengan orang lain (publik) untuk memperoleh saling pengertian di antara keduanya. Melalui hubungan baik tersebut, seorang Public Relations Officer dituntut menumbuhkan citra dan reputasi positif organisasi di mata khalayak. Dalam upayanya untuk memberikan gambaran dan pesan-pesan yang baik tentang organisasi ada prinsip-prinsip yang harus diikuti oleh PRO, di antaranya Tell the Truth, Prove it with Action, Listen to The Customer, Manage for Tomorrow, Conduct Public Relationss as If The Whole Company Depends On it, Remain Calm, Patient and Good Humored (Arthur W. Page) Prinsip ini sejalan dengan nilainilai dalam ajaran Islam sebagaimana tertuang dalam ayat al-Quran dan hadits Nabi Muhammad SAW. Anggota Perhimpuna Humas (Perhumas) Jawa Tengah yang umumnya beragama Islam dalam menjalankan profesinya sebagai Humas (PR) tentunya tidak lepas dari apa yang mereka pahami tentang prinsip-prinsip kebaikan dalam profesi PR sesuai agama Islam yang mereka anut. Oleh karena itu menjadi menarik untuk dikaji dan diungkapkan bagaimana pandangan mereka tentang prinsip PR sesuai dengan apa yang mereka pahami dalam ajaran Islam. Dalam upayanya untuk mengungkap persepsi mereka, digunakan pendekatan deskriptif kualitatif melalui pertanyaan terstruktur terhadap informan yang sudah ditentukan berdasarkan pertimbanganpertimbangan tertentu yang kemudian dianalisis dengan menggunakan model analisis interaktif untuk menghasilkan suatu kesimpulan.
\end{abstract}

Kata kunci : prinsip PR, persepsi, Islamic values

\begin{abstract}
Public Relations is a science and also a profession related to the efforts to build a good relationship with publics to gain benefitial mutual understanding. Through such good relationships, a Public Relations Officer (PRO) is required to cultivate a positive image and reputation of the organization in the audience's mind. In its efforts to provide a good picture and message about the organization, there are principles to be followed by PRO, among others; Tell the truth, Prove it with action, Listen to the customer, Manage for tomorrow, Conduct Public Relations as If the whole company depends on it, Remain calm, Patient and good humored (Arthur W. Page) This principles are in line with the Islamic values as contained in the Qur'an and the hadith of Prophet Muhammad Saw. The members of Perhimpunan Humas (Perhumas) of Central Java who are generally Muslim as a public relations (PR) certainly cannot be separated from what they understand about the principles of goodness in the profession of public relations according to their Islamic religion. Therefore becomes interesting to examine and disclose how their perception on PR principles fit into what they understand in the Islamic values. In an attempt to uncover their perception, a qualitative descriptive approach is used through structured questions of informants that have been determined based on certain considerations which are then analyzed by an interactive analysis model to generate a conclusion.
\end{abstract}

Keywords : principles of $P R$, perception, Islamic values 


\section{PENDAHULUAN}

Persepsi adalah pengalaman tentang objek, peristiwa, atauhubungan-hubungan yang diperoleh dengan menyimpulkan informasi dan menafsirkan pesan. Persepsi ialah memberikan makna pada stimuli indrawi (sensory stimuli). Hubungan sensasi dengan persepsi sudah jelas. Sensasi adalah bagian dari persepsi. Walaupun begitu, menafsirkan makna informasi indrawi tidak hanya melibatkan sensasi, tetapi juga atensi, ekspektasi, motivasi dan memori. (Rakhmat, 2005).

Pearson \& Nelson menerangkan bahwa persepsi memiliki tiga aktivitas, yaitu seleksi, organisasi, dan interpretasi. Yang dimaksudkan dengan seleksi mencakup tentang atensi dan sensasi. Sedangkan organisasi melekat dengan interpretasi, yang dapat didefinisikan sebagai "meletakkan rangsangan bersama rangsangan lainnya sehingga menjadi keseluruhan yang bermakna" (Mulyana, 2005).

Tahapan terpenting dalam persepsi adalah apa yang diperoleh melalui salah satu atau lebih indra yang nantinya akan melahirkan interpretasi atau informasi. Pengetahuan yang di peroleh melalui persepsi bukan pengetahuan mengenai objek yang sebenarnya, melainkan pengetahuan mengenai bagaimana tampaknya objek tersebut.

Anggota Perhumas Jawa Tengah yang merupakan insan profesional bidang Public Relations dengan latar belakang agama Islam, pendidikan formalinformal yang diperoleh dan pengalaman pekerjaan bidang komunikasi yang dijalani selama lebih dari 10 tahun, sedikit banyak telah membentuk persepsi mereka tentang profesi humas kaitannya dengan agama yang mereka anut. Pandangan mereka tentang prinsip kerja PR sangat dipengaruhi oleh apa yang mereka pahami dalam agama, apa yang mereka pelajari dalam pendidikan formal-informal, dan apa yang telah mereka lakukan selama mereka bekerja sebagai PR. Keseluruhan indra mereka telah menerima begitu banyak masukan rangsangan tentang apa itu prinsip PR dan bagaimana agama mereka mengajarkan tentang prinsipprinsip tersebut.

ArthurW.Pagetelahmengemukakan bahwa dalam menjalankan profesinya, PR memiliki prinsip kerja, yaitu Tell the Truth (berkata jujur, tidak berbohong), Prove it with Action (melakukan pembuktian atas apa yang sudah dikatakan melalui tindakan nyata), Listen to The Customer (mendengarkan apa yang diinginkan oleh pelanggan/publik), Manage for Tomorrow (merencanakan untuk esok hari), Conduct Public Relations as If the Whole Company Depends On it (melakukan pekerjaan sebagai PR dengan sungguh-sungguh seolah-olah keberhasilan organisasi sangat bergantung kepadanya), Remain Calm (tetap tenang, tidak terburu-buru), Patient (sabar) and Good Humored (memiliki selera humor yang baik).

Untuk melihat bagaimana persepsi atau pandangan mereka tentang prinsip PR dalam ajaran Islam kepada anggota Perhumas Jawa Tengah, maka dipilihlah 4 orang informan yang sudah ditentukan berdasarkan kesediaan mereka untuk memberikan informasi dan jawaban yang dibutuhkan. Keempatnya beragama Islam. Mereka bekerja di empat institusi yang berbeda yaitu Perguruan Tinggi Negeri (PTN), Perguruan Tinggi Islam Swasta (PTIS), media massa (MM), dan Rumah Sakit Islam (RSI). Dengan latar belakang institusi pekerjaan yang berbeda diharapkan akan melahirkan jawaban dan informasi yang lebih komprehensif sesuai dengan pengalaman mereka masinhgmasing.

Public Relations adalah sebuah keilmuan sekaligus profesi, yang berkaitan dengan usaha untuk membangun hubungan harmonis antara oranisasi dengan publik-publiknya sehingga dapat menghasilkan saling pengertian di 
antara keduanya, melahirkan citra positif organisasi, menumbuhkan kepercayaan publik dan meningkatkan reputasi. Dalam menjalankan profesinya, Public Relations dituntut untuk dapat menyampaikan pesan-pesan positif mengenai organisasi kepada publik melalui berbagai strategi dan taktik, sehingga apa yang disampaikan dapat memperoleh penerimaan dan pemahaman seperti yang diharapkan sesuai dengan tujuan organisasi.

Public Relations adalah Interaksi dan menciptakan opini publik sebagai input yang menguntungkan untuk kedua belah pihak, dan merupakan profesi yang profesional dalam bidangnya karena merupakan faktor yang sangat penting dalam pencapaian tujuan organisasi dengan secara tepat dan dengan secara terus menerus karena Public Relations merupakan kelangsungan hidup organisasi yang bersangkutan (Maria, 2002). Sedangkan Scholz (1999) berpendapat bahwa Public Relations adalah suatu perencanaan yang mendorong untuk mempengaruhi persepsi masyarakat melalui pelaksanaan tanggung jawab sosial berdasarkan suatu komunikasi timbal balik untuk mencapai keuntungan pada kedua belah pihak.

Public Relations merupakan semua bentuk komunikasi yang terencana, baik itu kedalam maupun keluar, antara suatu organisasi dengan semua khalayaknya dalam rangka mencapai tujuan-tujuan spesifik yang berlandaskan pada saling pengertian (Jefkins \& Yadin, 2003). Secara umum Public Relations adalah proses interaksi antara organisasi dengan publiknya di mana Public Relations berupaya untuk menciptakan opini publik sebagai input yang menguntungkan baik untuk organisasi maupun publiknya, menanamkan dan menumbuhkan pengertian, keinginan baik, motivasi dan partisipasi publik, meningkatkan kepercayaan dan citra yang baik.

Perhimpunan Humas (Perhumas)
Jawa Tengah adalah organisasi yang menghimpun individu-individu akademisi dan praktisi Humas/PR di wilayah Jawa Tengah. Anggota Perhumas Jawa Tengah umumnya beragama Islam, sehingga sedikit banyak nilai-nilai ajaran Islam ikut mempengaruhi bagaimana cara mereka bekerja menjalankan profesinya.

Meski tidak semuanya berlatar belakang keilmuan komunikasi atau kehumasan, tetapi mereka memiliki pengetahuan dan pengalaman yang baik dalam upaya membangun citra organisasi, menumbuhkan pengertain dan reputasi positif melalui komunikasi dan hubungan timbal balik yang terencana antara manajemen organisasi dengan publiknya, baik internal maupun eksternal.

Secara profesional para PR yang tergabung dalam Perhumas dituntut untuk menjalankan tugas-tugas pokok PR sebagaimmana yang disampaikan oleh Cutlip dkk (2009) yaitu: (1) Mendidik melalui kegiatan nonprofit suatu publik untuk menggunkan barang/ jasa instansinya. (2) Mengadakan usaha untuk mengatasi salah paham antara instansi dengan publik. (3) Meningkatkan penjualan barang atau jasa. Meningkatkan kegiatan perusahaan yang berkaitan dengan kegiatan masyarakat sehari-hari. (5) Mendidik dan meningkatkan tuntutan serta kebutuhan masyarakat akan barang dan jasa yang dihasilkan oleh perusahaan. (6) Mencegah pergeseran penggunaan barang atau jasa yang sejenis dari pesaing perusahaan oleh konsumen.

Selain menjalankan tugas sebagaimana disebutkan di atas, para PR ini juga dihadapkan pada peran yang sangat strategis bagi organisasi yaitu: (1) Membantu menetapkan serta memelihara garis komunikasi. (2) Memecahkan masalah-masalah manajemen. (3) Membantu para manajer untuk mengambil keputusan yang efektif. (4) Memberi peringatan dini kepada para 
manajer untuk mengantisipasi setiap kecenderungan. (5) Menggunakan riset dan teknik-teknik komunikasi sebagai sarana utama.

Dalam usahanya membangun komunikasi dengan berbagai publik baik di dalam organisasi maupun diluar organisasi melalui komunikasi langsung maupun tidak langsung, vertikal maupun horizontal, Public Relations seringkali dihadapkan pada situasi dimana mereka harus berkompromi dengan keadaan. Namun demikian ada standar yang harus mereka junjung tinggi diantaranya adalah PR harus memiliki niat yang baik berdasarkan etika yang jamak berlaku, mengedepankan trust dan berpondasikan pada kepercayaan, keyakinan dan nilainilai positif yang melindungi kepentingan dan martabat profesinya, organisasinya dan juga masyarakatnya.

Selain itu, PR juga memiliki prinsip kerja yang harus dipahami dan diikuti oleh PR sebagaimana yang ditulis oleh Arthur W. Page, yaitu: Tell the Truth (mengatakan yang benar), Prove it with Action (pembuktian atas apa yang dikatakan melalui aksi atau tindakan), Listen to The Customer (mendengarkan keinginan pelanggan, dalam hal ini publik organisasi) Manage for Tomorrow (memiliki perencanaan untuk hari esok), Conduct Public Relations as If the Whole Company Depends On it (melakukan yang terbaik seolah-olah bahwa seluruh organisasi sangat bergantung kepada PR), Remain Calm (tetap tenang), Patient (sabar) and Good Humored (memiliki selera humor yang baik).

Pentingnya membangun hubungan yang baik sehingga melahirkan pengertian diantara kedua pihak yang berkomunikasi juga menjadi bagian penting dalam ajaran Islam. Agama ini selain mengajarkan pengikutnya untuk menjalin hubungan dengan Sang Khalik (hablumminallah), juga memberikan tuntunan kepada umatnya untuk melakukan hubungan yang baik dengan sesama (hablumminannas).

Untuk itu, banyak sekali ayat dan hadis yang mengingatkan umat Islam tentang pentingnya menjaga hubungan baik melalui berbagai muamalah yang baik pula. Menjaga hubungan baik dengan orang lain dalam Islam dapat dimaknai sebagai silaturrahim. KH. Quraish Shihab mengatakan bahwa silaturrahim adalah menghangatkan yang dingin, mencairkan yang beku, dan meluruskan benang kusut. Dengan silaturrahim melalui jalinan hubungan yang baik akan mendatangkan banyak manfaat, sebagaimana disebutkan dalam sebuah hadis yang berbunyi,

"Barangsiapa yang ingin diluaskan
rezekinya dan ingin dipanjangkan
umurnya, maka hendaklah ia selalu
menjalin hubungan silaturahim".

Islam juga mengajarkan kepada umatnya bahwa silaturrahim yang baik haruslah dilakukan dengan cara yang baik, saling menghormati dan menghargai kepentingan yang dimiliki diantara mereka yang bersilaturrahim. Ajaran ini tentu saja sejalan dengan prinsip PR yang mengedepankan rasa saling menghargai kepentingan sehingga nantinya akan dicapai saling pengertian.

Pemahaman atas rinsip PR dan nilainilai ajaran Islam yang diyakininya akan sangat mempengaruhi pandangan mereka tentang praktik PR secara profesional. Selain itu, pengalaman mereka selama bergelut dalam profesi ini juga ikut mempengaruhi pandangan mereka tentang prinsip kerja PR. Oleh karena itu, disini peneliti akan mengungkapkan bagaimana persepsi/pandangan anggota Perhumas Jawa Tengah tentang prinsip PR dalam pandangan Islam.

\section{METODE}

Penelitian ini merupakan penelitian deskriptif kualitatif dengan pendekatan intepretif terhadap anggota Perhumas Jawa Tengah sebagai subyek penelitian 
kemudian ditentukan 4 orang informan yang dipilih berdasarkan beberapa pertimbangan. Data primer dikumpulkan melalui wawancara mendalam terhadap 4 infroman yang sudah ditentukan sebelumnya, sedangkan data sekunder diperoleh melalui kepustakaan dan sumber lain yang relevan dengan penelitian.

Teknik analisis yang digunakan dalam penelitian ini dilakukan dengan mengikuti model analisis interaktif (Miles \& Huberman, dalam Sutopo, 2002). Dalam penelitian ini terdapat tiga komponen analisis, yaitu reduksi data, sajian data, dan penarikan kesimpulan. Proses ini berlangsung terus-menerus selama penelitian berlangsung.

Validitas data dilakukan dalam rangka memastikan keabsahan data melalui teknik triangulasi. Teknik ini memungkinkan peneliti untuk menggunakan berbagai jenis data, yaitu orang (informan) yang memiliki profesi yang sama, waktu yang digunakan untuk mengumpulkan data dari para informan berbeda-beda, dan ruang di mana data dikumpulkan di 4 tempat yang berbeda sesuai dengan tempat di mana mereka bekerja, yaitu perguruan tinggi negeri, perguruan tinggi swasta, lembaga media, dan rumah sakit.

\section{TEMUAN DAN PEMBAHASAN}

Persepsi merupakan gambaran atau pandangan seseorang mengenai sesuatu. Dalam melakukan suatu profesi, persepsi seseorang terhadap profesi tersebut sangat menentukan bagaimana orang tersebut menjalani profesinya. Anggota Perhumas yang merupakan kumpulan orang yang terhimpun ke dalam suatu organisasi profesi kehumasan memiliki latar belakang yang berbeda-beda. Mulai dari perbedaan agama, pendidikan, budaya, dan lain-lain. Kesemua itu ikut memengaruhi bagaimana persepsi mereka terhadap prinsip kerja dalam profesi yang mereka jalani.
Dalam profesi PR dikenal prinsip kerja PR yang dikemukakan Arthur W. Page. Kepada 4 orang informan dari anggota Perhumas Jawa Tengah diperoleh pandangan mereka tentang prinsip PR dalam Islam. Yang pertama adalah prinsip kejujuran, dalam hal ini PR tidak boleh berbohong. Ini merupakan prinsip kerja PR yang paling mendapat perhatian. PR boleh saja mempunyai cita-cita yang tinggi, yaitu mendapatkan citra terbaik untuk organisasi, tetapi cita-cita tersebut harus diraih dengan penuh penghormatan terhadap profesinya dengan tidak melakukan kebohongan.

Menurut Keraf(1998)jujur dan setia serta merasa terhormat pada profesi yang disandangnya, mengakui kelemahannya dan tidak menyombongkan diri, serta berupaya terus untuk mengembangkan diri dalam mencapai kesempurnaan bidang keahlian dan profesinya melalui pendidikan, pelatihan, dan pengalaman. Di samping itu, tidak akan melacurkan profesinya untuk tujuan yang tidak dapat dipertanggungjawabkan demi tujuan materi semata atau kepentingan sepihak.

Kejujuran dalam Islam memiliki kedudukan yang penting. Sebab melalui kejujuran, kebenaran dapat ditegakkan. Dalam QS Al-Ahzab/33:70 Allah Swt berfirman, yang artinya,

"Wahai orang-orang yang beriman,
bertakwalah kamu kepada Allah dan
ucapkanlah perkataan yang benar".

Itu artinya, sebagai orang yang beriman kepada Allah, manusia dituntut untuk jujur, mengatakan hal yang benar sesuai dengan keadaan yang sebenarnya dan tidak berlawanan dengan apa yang dikerjakan. Dalam Islam, dosa hukumnya bila seorang Muslim mengatakan sesuatu, tetapi tidak sesuai dengan apa yang ia kerjakan. Tidak diperbolehkan dalam Islam bagi seorang PR Muslim yang menjalankan profesinya dengan cara berbohong, dengan mengatakan hal- 
hal yang baik mengenai organisasinya tetapi apa yang dikatakan tersebut tidak dilakukan. Allah Swt mengatakan dalam QS. Asshaf /61:1-2, yang artinya,

"Wahai orang-orang yang beriman, mengapa kamu mengatakan sesuatu yang tidak kamu kerjakan? Itu sangatlah dibenci di sisi Allah jika kamu mengatakan apa-apa yang tidak kamu kerjakan".

Prinsip kejujuran dan melakukan apa yang dikatakan merupakan dua dari prinsip kerja PR yang disampaikan oleh Arhur W. Page yaitu tell the truth dan prove it with action. Atas dasar pemahaman keagamaan dan pengalaman mereka dalam menjalankan profesinya sebagai PR, anggota Perhumas Jawa Tengah memiliki pandangan yang baik mengenai dua prinsip PR ini. Mereka sepakat bahwa menyampaikan hal-hal yang baik mengenai organisasi adalah tugas PR, tetapi harus disampaikan dengan cara yang baik pula, yaitu tidak berbohong. Mereka tahu bahwa tidak ada organisasi yang sempurna tanpa cela. Tetapi, tidak mungkin bagi PR untuk mengumbar kejelekan tersebut kepada publik. Namun, bukan berarti PR berbohong karena tidak mengatakan keburukan/kelemahan organisasi kepada publik.

Untuk menghindari berbohong, salah satu informan mengatakan bahwa PR harus memiliki batasan mana yang penting dan tidak penting untuk disampaikan kepada khalayak. Terlebih bagi informan yang bekerja sebagai PR di Rumah Sakit Islam di mana manajemen memasukkan nilai-nilai Islam dalam sistem pelayanannya. Mereka hanya boleh mengatakan sesuai dengan apa yang sebenarnya sebagaimana keadaan di RS.

Selain prinsip kejujuran dan melakukan atau membuktikan apa yang sudah disampaikan kepada khalayak, PR juga harus berpegang pada prinsip listen to the custommer. Untuk itu, selain mengatakan apa yang perlu dikatakan kepada khalayak dalam upayanya mempersuasi dan memengaruhi opini publik, PR juga harus memiliki kemampuan mendengar yang baik.

Dalam proses komunikasi untuk memperoleh umpan balik, maka mendengar adalah satu tahapn komunikasi yang harus memperoleh perhatian khusus. Terlebih bagi PR, yang tugasnya adalah menjalin komunikasi timbal balik dengan publik organisasi. Bagaimanapun publiklah yang menentukan eksistensi organisasi di tengah masyarakat. Segala strategi dipakai untuk memperoleh pengertian dan perhatian dari mereka. Oleh karena itu, organisasi harus mendengar apa yang dikehendaki oleh mereka dari organisasi. Sebagaimana Rasulullah Saw mengajarkan kepada umatnya untuk senantiasa menjadi pendengar untuk mengetahui keinginan orang lain. Kisah kenabian Rasulullah banyak mengungkap betapa Rasulullah adalah sebaik-baiknya pendengar. Oleh karena itu, banyak ayat Allah yang turun setelah melalui proses mendengar yang dilakukan oleh Rasulullah.

Salah satu informan yang mengidolakan Rasulullah sebagai panutan hidupnya mengatakan bahwa mendengar merupakan bagian dari komunikasi yang sehat. Kemauan untuk mendengar adalah bagian dari adab dalam berkomunikasi. Terlebih komunikasi yang berkembang dalam PR era sekarang adalah two way symetrical communication. Maka mendengar apa yang dikehendaki oleh publik menjadi mutlak. Mendengar bagi PR dalam hal ini bukan hanya semata mendengar secara harfiah, tetapi juga bagaimana kemauan PR untuk menggunakan segenap pancainderanya untuk menangkap apa pesan yang tersurat maupun tersirat dari publik. Riset adalah 
salah satu metode yang digunakan oleh PR untuk menangkap apa dan bagaimana keinginan publik.

Kemampuan untuk jujur, konsisten atas apa yang diucapkan dengan apa yang dilakukan serta kemampuan mendengar yang baik tentunya modal yang sangat bagus bagi seorang PR. Tetapi, bila tidak dibarengi dengan kemampuan perencanaan yang baik maka kelebihan tersebut tidak akan banyak dampaknya bagi PR maupun organisasi yang diwakilinya. Oleh karena itu, kemampuan manage for tomorrow adalah prinsip PR selanjutnya yang harus dipahami oleh $P R$ officer.

Islam mengajarkan pentingnya perencanaan dalam hidup, sebab perencanaan adalah proses paling awal dalam mencapai suatu tujuan. Dalam QS; Al-Hasyr/59:18 Allah berfirman yang artinya, "Wahai orang orang yang beriman, bertakwalah kepada Allah dan hendaklah setiap orang memperhatikan apa yang telah diperbuatnya untuk hari esok (akhirat), dan bertakwalah kepada Allah. Sumhhuh, Allah Maha Mengetahui terhadap apa yang kamu kerjakan".

Sebagai Muslim, anggota Perhumas memiliki pandangan yang sejalan dengan prinsip PR yang satu ini. Bagi mereka yang sudah menjalani profesi PR selama bertahun-tahun, perencanaan adalah sesuatu yang mutlak. Sebab, PR memang adalah satu komunikasi terencana yang dilakukan terus-menerus untuk mencapai tujuan yang ingin dicapai.

Jauh sebelum belajar tentang PR, agama Islam juga telah mengajarkan kepada mereka tentang pentingnya membuat rencana. Sebuah perencanaan akan dapat menjadi bahan evaluasi tentang keberhasilan atau kegagalan suatu proses dan hasil. Oleh karena itu, di dalam perencanaan juga mengandung muhasabah yang dilakukan terus-menerus sebagai upaya untuk memperbaiki dari apa yang sudah dilakukan. Demikian juga dengan proses PR, yang selalu diawali dengan sebuah perencanaan dan kemudian diakhiri dengan evaluasi melalui riset sebagai bagian dari muhasabah. Hasil muhasabah ini akan menjadi modal untuk membuat perencanan berikutnya. Begitu terus.

Dalam Islam ada pepatah yang berbunyi "hari ini harus lebih baik dari hari kemarin". Bahkan, dalam sebuah hadis Nabi dikatakan bahwa,

"Barangsiapa yang harinya sekarang lebih baik dari hari kemarin maka dia termasuk orang yang beruntung. Barangsiapa yang harinya sama dengan hari kemarin maka dia orang yang merugi. Barangsiapa yang harinya sekarang lebih buruk daripadanya hari kemarin maka dia terlaknat".

Meski hadis ini menurut beberapa pakar hadis dianggap sebagai hadis dhaif (lemah), tetapi muatan yang terkandung dialamnya telah mengajarkan kepada umat Islam mengenai pentingnya sebuah perencanaan agar hari esok lebih baik dari hari ini.

Jadi, perencanaan yang baik adalah kunci awal keberhasilan seorang PR. Untuk menjalankan rencana supaya mencapai tujuan yang diharapkan, yaitu terbentuknya citra positif organisasi, adanya pengertian, dukungan, dan kepercayaan publik terhadap organisasi, maka seorang PR harus bekerja dengan sangat sungguh-sungguh seolah-olah seluruh organisasi sangat bergantung kepadanya. PR harus bekerja secara total. Conduct Public Relations as If the Whole Company Depends On it. Ini adalah prinsip PR selanjutnya yang harus menjadi perhatian para $P R$ officer.

Prinsip PR ini sejalan dengan apa yang anggota Perhumas Jawa Tengah pahami dalam ajaran agama Islam yang mereka anut. Rasulullah mengajarkan kepada umatnya untuk sepenuh hati 
bekerja seolah-olah kita akan hidup selamanya untuk menikmati hasil pekerjaan kita. Sebagaimana sabdanya yang berbunyi,

"Bekerjalah untuk duniamu seakanakan kamu hidup selamanya. Dan beribadahlah untuk akhiratmu seakanakan kamu akan mati besok".

Sejalan dengan hadis Nabi di atas, anggota Perhumas Jawa Tengah juga berpandangan bahwa sebagai PR yang profesional, haruslah selalu bersungguhsungguh dalam mencapai setiap tujuan yang direncanakan. Sebab, baik buruk organisasi di hadapan masyarakat sangat bergantung kepada kinerja mereka. Tak terbayangkan bila masyarakat memiliki pandangan negatif tentang organisasi, tentu akan sangat sulit bagi organisasi untuk mencapai tujuannya. Terlebih bagi organisasi yang sangat mengandalkan dukungan publik, seperti organisasi yang menjual produk atau jasa, sebagaimana tempat keempat informan anggota Perhumas Jawa Tengah ini bekerja.

Salah satu informan yang bekerja di sebuah perguruan tinggi Islam swasta mengatakan bahwa "inti dari profesi Humas adalah dengan sepenuh hati memiliki niat baik yang dibangun sehingga akan mewujud dalam setiap apapun yang dilakukan. Dan imbasnya akan dirasakan oleh organisasi".

Bekerja sepenuh hati sebagai seorang PR, tentu memerlukan pemikiran dan sikap yang tenang, tidak grasa-grusu, remain calm. Ada pepatah mengatakan bahwa ketenangan merupakan sumber kekuatan yang besar (Lao Zu). Sebagai fungsi manajemen, PR seringkali berhadapan dengan pengambilanpengambilan keputusan penting organisasi yang tentunya memerlukan pemikiran yang tenang dan analisa yang mendalam. Dalam menghadapi publik yang memiliki latar belakang dan karakter yang berbedabeda juga memerlukan ketenangan sehingga kita dapat mempersuasi mereka untuk mau menerima dengan sukarela apa yang kita sampaikan.

Rasulullah sebagai panutan umat Islam telah memberikan contoh tentang bersikap tenang. Pada saat menyebarkan agama Illahi, Rasulullah harus menghadapi pertentangan yang luar biasa dari kaum Quraisy Makkah. Rasulullah selalu bersikap tenang dan konsisten terus-menerus menyampaikan pesanpesan kebaikan tentang Islam, sehingga lambat laun kaum Quraisy yang tadinya menolak bahkan memusuhi nabi pada akhirnya mau menerima Islam sebagai agama mereka. Sebagaimana firman Allah dalam QS. Ali Imran/3:159 yang artinya,

"Maka disebabkan rahmat dari Allah-lah kamu berlaku lemah lembut terhadap mereka. Sekiranya kamu bersikap kasar lagi berhati kasar, tentulah mereka menjauhkan diri dari sekelilingmu....".

Salah satu informan berpandangan bahwa sikap tenang sebagaimana prinsip PR dan juga yang diajarkan oleh Rasulullah berarti mampu mengendalikan diri dan bertindak cepat, tanggap, dan tepat dalam menentukan sikap. Oleh sebab itu, seorang PR harus memiliki tingkat kejeniusan dan pengendalian emosi yang tinggi, sehingga mampu menghadapi berbagai situasi dan kondisi yang menekan sekalipun dalam keadaan tetap terkontrol.

Ketenangan selalu diikuti dengan kesabaran. Keduanya adalah seperti dua sisi mata uang yang tak terpisahkan. Untuk dapat besikap tenang, maka diperlukan kesabaran (patient). Dalam menjalankan tugas dan fungsinya dalam rangka memperoleh good will dari publik, tentu diperlukan jalan panjang yang melelahkan dan membutuhkan kesabaran yang luar biasa dari PR officer. Anggota Perhumas Jawa Tengah 
memahami tentang arti kesabaran dalam tugas yang melekat pada mereka. Ajaran tentang sabar dalam agama Islam yang mereka yakini telah memengaruhi pandangan mereka dalam menghadapi berbagai situasi dan kondisi, sebab Allah berfirman dalam QS. Al-Baqoroh/2:153 yang artinya "sesungguhnya Allah bersama orang-orang yang sabar". Dalam QS. An-Nahl/16:126, yang artinya, "Dan sesungguhnya Kami memberi balasan kepada orang-orang yang sabar dengan ganjaran yang lebih baik dari apa yang telah mereka kerjakan". Dalam suatu hadis yang diriwayatkan oleh atTirmidzi, dari Ibnu Abbas ra, bahwasanya Nabi bersabda; "Ketahuilah olehmu bahwa pertolongan itu bersama dengan kesabaran". Dan masih banyak lagi ayatayat dan hadis yang mengupas tentang kesabaran".

Anggota Perhumas Jawa Tengah memandang bahwa sabar merupakan sikap mutlak yang harus dimiliki oleh siapa saja yang bekerja di bidang komunikasi publik. Menurut salah satu informan,

\begin{abstract}
"Sama seperti sikap tenang, kesabaran juga sangat diperlukan. Sabar dalam menggali informasi dari publik, sabar dalam menunggu perkembangan informasi, dll. Secara internal, sabar juga sangat diperlukan ketika berhadapan dengan kolega, khususnya untuk program-program yang melibatkan kerja tim. Pada intinya, kesabaran sangat diperlukan untuk menghasilkan sesuatu yang maksimal".
\end{abstract}

Pendapat ini tidak lepas dari pemahamannya sebagai seorang muslim ketika bertahun-tahun berhadapan dengan pekerjaan yang berkaitan dengan komunikasi publik di sebuah media.

\section{SIMPULAN}

Berdasarkan

pembahasan dapat disimpulkan bahwa, (1) Anggota Perhumas memiliki persepsi yang sama tentang prinsip PR dalam ajaran Islam, meski cara mengekspresikan persepsi tersebut berbeda-beda sesuai dengan perbedaan latar belakang masing-masing, (2) Sebuah perhimpunan profesi memiliki etika yang mengikat agar anggota tidak lepas kendali dalam menjalankan profesinya. Ada rambu-rambu yang harus diikuti. Agama Islam telah mengajarkan kepada umatnya untuk menjunjung prinsip kerja positif. "SesungguhnyaAllah mencintai salah seorang diantara kamu yang melakukan suatu pekerjaan dengan baik" (HR. Muslim), (3) Public Relations atau Humas, dalam kesehariannya akan berinteraksi dengan manusiamanusia lain yang harus dipahamkan olehnya tentang hal-hal positif tentang organisasi, meminimalisir pandangan negatif terhadap organisasi, mendapatkan dukungan dan pengakuan publik, harus dilakukan dengan penuh kehormatan.

\section{DAFTAR PUSTAKA}

Cutlip, S. M., Center, A. H. \& Broom, G. M. (2009). Effektif Public Relations, Jakarta: Kencana.

Jefkins, F. \& Yadin, D. (2003). Public Relations. Jakarta: Erlangga

Keraf, S. (1998). Etika Bisnis Tuntutan dan Relevansinya, Yogyakarta: Kanisius.

Maria. (2002) Dasar-dasar Public Relation, Jakarta, PT. Grasindo

Mulyana, D. (2005). Ilmu Komunikasi Suatu Pengantar. Bandung: PT. Remaja Rosdakarya

Rakhmat, J. (2005). Psikologi Komunikasi. Bandung: PT.Remaja Rosdakarya

Sutopo. (2002). Metodologi Penelitian Kualitatif Dasar Teori dan Terapannya dalam Penelitian. Surakarta: UNS Press. 